\title{
Proximate and Protein Compositions of Requiem Shark Muscle
}

\author{
Shugo Watabe*, Yoshihiro Ochiai*, Satoshi Kanoh*, \\ and Kanehisa HaSHIMOTO*
}

(Accepted June 24, 1982)

\begin{abstract}
Proximate and protein compositions of the ordinary muscle of requiem shark Triakis scyllia were examined. The proximate composition of the dorsal muscle was: moisture $76.0 \%$, crude protein $24.9 \%$, crude fat $2.7 \%$, and crude ash $1.3 \%$. The protein content corrected for urea $(5.4 \mathrm{mgN} / \mathrm{g})$ and for non-protein nitrogenous compounds $(11.2 \mathrm{mgN} / \mathrm{g}$ ) was $21.5 \%$ and $17.5 \%$, respectively.

The protein compositions of the dorsal and ventral muscle remained unchanged essentially through pre-, in-, and post-rigor stages: In the dorsal part, sarcoplasmic 22.1-25.9\% (av. $24.5 \%$ ), myofibrillar 60.1-66.8\% (63.2\%), alkali-soluble 4.1-5.5\% (4.7\%), and stroma fraction $6.5-8.9 \%$ $(7.6 \%)$. In the ventral part, corresponding data were $20.4-26.1 \%(24.2 \%), 58.4-67.2 \%(63.5 \%)$, $2.9-9.2 \%(6.1 \%)$, and $3.8-8.2 \%(6.1 \%)$, respectively. The protein composition of each muscle did not show any significant changes after a 2 -week frozen storage at $-20^{\circ} \mathrm{C}$.
\end{abstract}

Marine elasmobranchs osmoregulate the blood and other body fluids in conformity to the environment, by means of nitrogenous compounds such as urea and trimethylamine oxide. ${ }^{1-4)}$ The urea levels up to $460 \mathrm{~mm}$ have so far been determined in their body fluids. ${ }^{1)}$ After their death, urea is gradually decomposed into ammonia, lowering the meat quality. ${ }^{\text {s) }}$

Since urea is a protein denaturant, proteins of an elasmobranch are supposed to be urea-resistant, or be protected from denaturation by some mechanism(s). In fact, the hemoglobins of the elasmobranch fishes such as Raja eglanteria, Torpedo nobiliana, etc., were found to be more urea resistant than human hemoglobin." No corresponding studies have been carried out on muscle proteins of elasmobranchs.

The present series of study was started under the above situations, and this paper deals with the proximate and protein compositions of the muscle of requiem shark.

\section{Materials and Methods}

\section{Materials}

Live specimens of the requiem shark, "dochizame" Triakis scyllia $(4.6 \mathrm{~kg}$ in average body weight) were supplied from the Enoshima Aquarium. After decapitation, dorsal and ventral parts of the ordinary muscle were carefully excised and analyzed for proximate and protein compositions. as described below. In addition, the blood serum prepared as usual and the liver were assayed for urea. The dorsal muscle of sea bass Lateolabrax japonicus ( $0.9 \mathrm{~kg}$ in body weight) was analyzed for protein composition for comparison.

\section{Analytical Methods}

Urea was determined enzymatically by the method of Gutmann and Bergmeyer." Proximate composition was determined as usual on the dorsal muscle from requiem shark. Protein composition was assayed by the method reported previously, ${ }^{8)}$ on the muscles of shark and sea bass in pre-, in-, and post-rigor stages. A portion of the muscle of each fish was stored at $-20^{\circ} \mathrm{C}$ for 2 weeks, and similarly analyzed.

\section{Results and Discussion}

Urea

Urea concentrations of requiem shark were $194 \mathrm{~mm}$ in dorsal muscle, $195 \mathrm{~mm}$ in blood serum, and $175 \mathrm{~mm}$ in liver. A range from 200 to $460 \mathrm{~mm}$ has so far been reported for the tissues of some marine elasmobranchs such as Raja stabuloforis, ${ }^{1}{ }^{1}$ Norcine brasiliensis, ${ }^{12}$ and Squalus acanthias. ${ }^{9)}$

\section{Proximate Composition}

The proximate composition of shark dorsal muscle was moisture $76.0 \%$, crude protein $24.9 \%$,

* Lab. of Marine Biochem., Fac. of Agric., The Univ. of Tokyo, Bunkyo, Tokyo 113, Japan (洨部終五 •

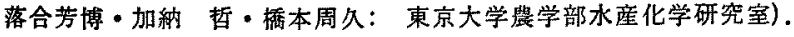


crude fat $2.7 \%$, and crude ash $1.3 \%$, the total being $104.9 \%$. When corrected for urea nitrogen $(5.4 \mathrm{mg} / \mathrm{g}$, as calculated from the above datum) and for non-protein nitrogen $(11.2 \mathrm{mg} / \mathrm{g}$, as described below), the protein contents of 21.5 and $17.5 \%$ were obtained, respectively. The proximate compositions thus corrected resemble those of sluggish teleostean fishes such as cod and plaice featuring in a low fat content. ${ }^{10}$ )

The urea nitrogen to non-protein nitrogen ratio was calculated to be $48 \%$. The values of 47 $60 \%$ have so far been reported for various marine elasmobranchs. ${ }^{11)}$

\section{Protein Composition}

The protein compositions of both shark muscles in various stages are shown in Table 1 . Nonprotein nitrogen contents of the dorsal and ventral muscles were 11.2 and $12.3 \mathrm{mgN} / \mathrm{g}$, respectively, on an average. These values are considerably higher than that of sea bass muscle, $2.9 \mathrm{mgN} / \mathrm{g}$ (refer to Table 2). The differences can reasonably by accounted for by those of urea.

As shown in Table 1, the protein nitrogen level as well as protein composition of shark muscle did not differ widely between both muscles, and among the pre-, in-, post-rigor, and frozen sam-

Table 1. Protein compositions of dorsal and ventral muscles from pre-, in-, post-rigor, and frozen requiem shark samples

\begin{tabular}{|c|c|c|c|c|c|c|}
\hline \multirow{2}{*}{ Sample } & \multirow{2}{*}{$\begin{array}{l}\text { Part of } \\
\text { muscle }\end{array}$} & \multirow{2}{*}{$\begin{array}{l}\text { Non-protein } \\
\text { nitrogen }\end{array}$} & \multicolumn{4}{|c|}{ Protein nitrogen } \\
\hline & & & Sarcoplasmic & Myofibrillar & Alkali-soluble & Stroma \\
\hline \multirow[t]{4}{*}{ Pre-rigor } & Dorsal & 11.1 & 5.8 & 17.5 & 1.2 & 1.7 \\
\hline & & & $(22.1)^{* 1}$ & $(66.8)$ & $(4.6)$ & $(6.5)$ \\
\hline & Ventral & 13.1 & 5.5 & 17.5 & -1.7 & 2.2 \\
\hline & & & (20.4) & $(65.0)$ & (6.3) & $(8.2)$ \\
\hline \multirow[t]{4}{*}{ In-rigor } & Dorsal & 11.2 & 6.9 & 16.3 & 1.5 & 2.4 \\
\hline & & & $(25.5)$ & $(60.1)$ & $(5.5)$ & $(8.9)$ \\
\hline & Ventral & 12.6 & 6.5 & 14.6 & 2.3 & 1.6 \\
\hline & & & $(26.0)$ & $(58.4)$ & $(9.2)$ & $(6.4)$ \\
\hline \multirow[t]{4}{*}{ Post-rigor } & Dorsal & 11.1 & 6.3 & 15.2 & 1.0 & 1.8 \\
\hline & & & $(25.9)$ & $(62.6)$ & $(4.1)$ & $(7.4)$ \\
\hline & Ventral & 11.4 & 6.2 & 16.0 & 0.7 & 0.9 \\
\hline & & & $(26.1)$ & $(67.2)$ & (2.9) & $(3.8)$ \\
\hline \multirow[t]{4}{*}{ Frozen*2 } & Dorsal & 11.5 & 7.0 & 15.6 & 1.8 & 3.1 \\
\hline & & & $(25.5)$ & $(56.7)$ & $(6.5)$ & $(11.3)$ \\
\hline & Ventral & 12.0 & 5.9 & 16.8 & 0.7 & 1.4 \\
\hline & & & $(23.8)$ & $(67.7)$ & $(2.8)$ & $(5.6)$ \\
\hline
\end{tabular}

*1 Numbers in parenthesis represent percentage distribution.

(2) Kept frozen at $-20^{\circ} \mathrm{C}$ for 2 weeks.

Table 2. Protein compositions of dorsal muscle from pre-, in-, post-rigor, and frozen sea bass samples

$\mathrm{mgN} / \mathrm{g}$ muscle

\begin{tabular}{lccccc}
\hline \multirow{2}{*}{ Sample } & \multirow{2}{*}{$\begin{array}{c}\text { Non-protein } \\
\text { nitrogen }\end{array}$} & \multicolumn{4}{c}{ Protein nitrogen } \\
\cline { 3 - 6 } & \multirow{nnyyyy}{*}{ Pre-rigor } & Sarcoplasmic & Myofibrillar & Alkali-soluble & Stroma \\
\hline In-rigor & 3.0 & 7.0 & 14.4 & 3.7 & 1.1 \\
& 3.0 & $(26.7)^{* 1}$ & $(55.0)$ & $(14.1)$ & $(4.2)$ \\
\hline Post-rigor & 2.6 & $(28.0)$ & $(65.0$ & 1.0 & 0.8 \\
& & 6.5 & 17.5 & $(3.9)$ & $(3.4)$ \\
\hline Frozen $^{* 2}$ & 3.2 & $(24.8)$ & $(66.8)$ & $(5.0)$ & $(3.4)$ \\
\hline
\end{tabular}

*1 Numbers in parenthesis represent percentage distribution.

*2 Kept frozen at $-20^{\circ} \mathrm{C}$ for 2 weeks. 


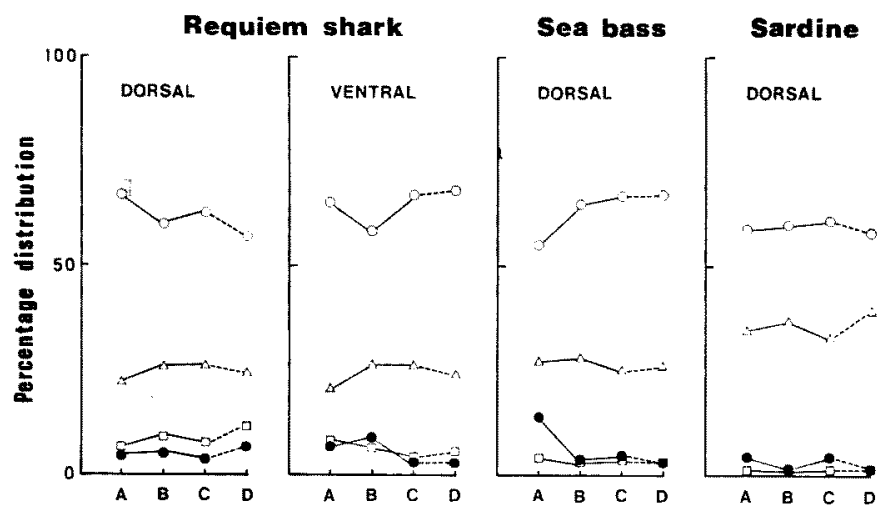

Fig. 1. Changes in protein composition of the ordinary muscles from requiem shark, sea bass, and sardine. ${ }^{6)}$ A, pre-; B, in-; and C, post-rigor stage; and D, after a 2-week frozen storage at $-20^{\circ} \mathrm{C}$. Symbols in the figure are; sarcoplasmic $\Delta$, myofibrillar $O$, alkali-soluble $\bullet$, and stroma protein fraction $\square$.

ples. The protein nitrogen level $(23.8-27.5 \mathrm{mgN} /$ g) was comparable to that of sea bass, 25.7$28.1 \mathrm{mgN} / \mathrm{g}$ (Table 2).

The protein composition of shark dorsal muscle in the three rigor stages was sarcoplasmic $22.1-25.9 \%$ (av. $24.5 \%$ ), myofibrillar $60.1-66.8 \%$ $(63.2 \%)$, alkali-soluble $4.1-5.5 \%(4.7 \%)$ and stroma $6.5-8.9 \%(7.6 \%)$. The protein composition of the ventral part was 20.4-26.1\% (av. $24.2 \%), 58.4-67.2 \%(63.5 \%), 2.9-9.2 \%(6.1 \%)$, and $3.8-8.2 \%(6.1 \%)$, respectively. Both muscles of the shark exhibited similar protein compositions after the frozen storage, as shown in Table 1.

The sarcoplasmic protein content $(20.4-26.1 \%)$ was roughly comparable to that of sea bass (24.8-28.0\%) and other sluggish teleosts (18$31 \%),{ }^{12)}$ but much lower than that of sardine $\left.(34.7-39.4 \%){ }^{8}\right) \quad$ It is noteworthy that the stroma content of requiem shark muscle $(3.8-11.3 \%)$ is comparable to those of other elasmobranchs $(7-12 \%), 12,13)$ and clearly higher than those of sea bass $(3.1-4.2 \%)$ and other teleosts $(2-4 \%){ }^{12,14)}$

Changes in the protein composition of both shark muscles through rigor stages and after the frozen storage are illustrated in Fig. 1 for detailed comparison. The corresponding data for sea bass and sardine dorsal muscle ${ }^{\beta)}$ are also included in the figure. In requiem shark dorsal muscle, myofibrillar protein accounted for $66.8 \%$ of the total in pre-rigor, and then decreased to $60.1 \%$ in in-rigor stage, with some concomitant increase of sarcoplasmic and alkali-soluble fractions. The dorsal muscle, when kept frozen, showed the lowest myofibrillar $(56.7 \%)$ and the highest stroma level $(11.3 \%)$. The ventral muscle showed the lowest myofibrillar level in in-rigor stage, but the highest after the frozen storage.

In contrast to those data for requiem shark muscles, sea bass muscle showed the lowest myofibrillar and the highest alkali-soluble levels in pre-rigor stage, no significant changes occurring among in-, post-rigor, and frozen samples. As seen in Fig. 1, the myofibrillar protein level of sardine muscle is fairly constant through all these samples. ${ }^{8)}$

Further investigations are now in progress to characterize elasmobranch muscle proteins.

\section{Acknowledgements}

The authors express their sincere thanks to Dr. Y. Hirosakr and Mr. K. Sezaki, the Enoshima Aquarium, for supplying the requiem sharks. Thanks are also due to Professor C. SHImizu, the Fishery Laboratory at Maisaka, The University of Tokyo, for collecting the live sea basses. The expenses of the present study were partly defrayed by a Grant-in-Aid from the Ministry of Education, Science and Culture.

\section{References}

1) W. N. Holmes and E. M. Donaldson: in "Fish Physiology" (ed. by W. S. Hoar and D. J. Randall), Vol. 1, Academic Press, New York, 1969, pp. 1-89.

2) P. K. T. Pang, R. W. Griffith, and J. W. Atz: Amer. Zool., 17, 365-377 (1977). 
3) H. W. Smith: J. Biol. Chem., 81, 407-419 (1929).

4) H. W. SMITH: Biol. Rev., 11, 49-82 (1936).

5) H. NOda, H. AMano, and Y. HoRiguch: Bull. Fac. Fish. Mie Univ., No. 5, 165-171 (1978).

6) J. Bonaventura, C. Bonaventura, and B. Sullivan: Science, 186, 57-59 (1974).

7) I. Gutmann and H.U. BerGmeyer; in "Methods of Enzymatic Analysis" (ed. by U. H. BerGMEYER), Vol. 4, Academic Press, New York, 1974, pp. 1791-1798.

8) K. Hashimoto, S. Watabe, M. Kono, and K. SHro: Bull. Japan. Soc. Sci. Fish., 45, 14351441 (1979).
9) S. N. JHAveri and S. M. Constantinides: $J$. Food Sci., 47, 188-192 (1981).

10) Resources Council, Science and Technology Agency: Standard Tables of Food Composition in Japan, 3rd Ed., Printing Bureau, Ministry of Finance, 1980, pp. 48-87.

11) M. Suyama and H. SuzukJ: Bull. Japan. Soc. Sci. Fish., 41, 787-790 (1975).

12) Y. Shimizu and W. Shimidu: Bull. Japan. Soc. Sci. Fish., 26, 806-809 (1960).

13) K. BAILEY: Biochem., J. 33, 255-263 (1939).

14) W. J. Dyer, H. V. French, and J. M. SNOW: J. Fish. Res. Bd. Can., 7, 585-593 (1950). 